\title{
PERTANGGUNGJAWABAN RETRIBUSI PARKIR DI DINAS PERHUBUNGAN KOTA PALEMBANG TAHUN 2018
}

\author{
Abdul Rauf ${ }^{1}$, Sisca Nopralia ${ }^{2}$ \\ 1) Staf Pengajar Fakultas Imu Administrasi Universitas Sjakhyakirti Palembang \\ ${ }^{2)}$ Staf Pengajar Fakultas Imu Administrasi Universitas Sjakhyakirti Palembang \\ Email : abdul_rauf@unisti.ac.id, sisca_nopralia@unisti.ac.id
}

\begin{abstract}
ABSTRAK
The research entitled "The Parking Fees in Transportation Agencies In Palembang", aimed to determine the accountabilty of acceptance parking fees by Transportation Agencies in Palembang through qualitative aspect of receiving report, developed from approach of public accountability. The method in this research uses qualitative method in the form of descriptive. The data retrieval techniques are about observation, interview, and documentation. This research uses public accountability theory which is explained by J. B Ghartey is about the collection of parking fees. The actor who is involved in collecting of parking fees and the value which is got from collecting the parking fees.
\end{abstract}

Kata Kunci: Pertanggungjawaban, Distribusi Parkir.

\section{PENDAHULUAN}

Sejarah pemungutan pajak pada umumnya secara singkat dapat digambarkan sebagai berikut: Di Zaman purbakala orang menganggap sangat bijaksana dan berbudi luhur untuk secara sukarela turut serta memelihara terhadap berlangsungnya kehidupan Negaranya, seperti halnya dengan pikiran rakyat dari Negara Yunani Purba. Juga sampai dengan abad pertengahan, yaitu antara 476 Masehi, tahun jatuhnya kerajaan Romawi-Barat dan tahun 1492, tahun diketemukannya Benua Amerika, pemungutan pajak secara paksa belum dikenal.

Pengeluaran para Raja pada waktu itu dibiayai dengan penghasilan dan kekayaan pribadinya, bahkan pengeluaran bagi keperluan Negarapun ditutup dengan pengahasilan dan kekayaan para raja. Hanya dalam keadaan yang sangat mendesak sekali, apabila ternyata bahwa pengeluaran-pengeluaran akan melebihi pendapatan pribadi raja, maka barulah disampaikannya suatu permintaan kepada rakyat akan sumbangan berupa barang atau uang.
Permintaan seperti itu dalam bahasa Belandanya disebut "BEDE".

Lambat laun pemintaan itu kemudian berubah menjadi suatu paksaan. Proses sifat paksaan tersebut dimulai setelah kerajaan-kerajaan memperluas wilayahnya dengan cara menundukkan suku bangsa lain yang dijajahnya. Rakyat jajahan itu dengan sendirinya tanpa adanya paksaan tidak akan memberikan sumbangan untuk memelihara benlangsungnya Negara.

Pungutan pajak pada waktu itu diserahkan kepada alat-alat bersenjata (tentara) yang pada saat tertentu menyerbu kepasar-pasar atau menghadang pedagang dipersimpangan jalan untuk meminta sebagian dari harta kekayaannya bagi keperluan pemeliharaan Negara. Pemungutan pajak yang sewenang-wenang seperti yang disebutkan diatas dalam zaman moderen itu dinilai sudah tidak pada tempatnya. Pungutan pajak sekarang harus didasarkan dan dilaksanakan menurut asas-asas dan norma Hukum yang disampingnya masih memperhatikan hal-hal seperti: 
1. Keadilan, dalam arti bahwa pungutan itu harus bersifat umum, merata, dan menurut kekuatan;

2. Ekonomis dapat diterima, yakni bahwa pungutan itu tidak akan merusak sumber-sumber kemakmuran rakyat;

3. Dapat mencapai tujuannya, dalam arti bahwa pungutan itu jangan sampai akan mengakibatkan adanya kemungkinan penyelundupan atau pengurangan hasil karena taripnya terlalu tinggi.

Selanjutnya untuk setiap pemungutan suatu pajak baru selalu harus diperhatikan pertanyaan-pertanyaan:

a. Berapa yang akan dihasilkan;

b. Tempat dan fungsinya dalam perekonomian rakyat.

Asas-asas seperti yang dikemukakan diatas itu semuanya harus dapat dituangkan dalam suatu peraturan pajak yang sifatnya praktis, dalam arti dapat dilaksanakan, adil dan sederhana susunannya. Sederhana dalam arti bahwa peraturan-peraturan itu mudah dapat ditangkap dan dimengerti oleh Wajib Pajak (WP).

Meskipun asas kesederhanaan selalu diperhatikan oleh pengundang-undang, akan tetapi perkembangan perundang-undangan pajak dewasa ini memberikan kenyataan bahwa peraturanperaturan pajak makin lama makin menjadi sulit untuk dapat diselami oleh para wajib pajak tanpa bantuan dari tenaga ahli berupa konsulin pajak dan sebagainya.

Pemungutan pajak yang dilakukan sekarang pada masyarakat yang berkembang dan telah maju, baik di Indonesia maupun di negaranegara lainnya telah dilakukan dengan modemisasi, namun perlu diingat bahwa sebelum kehidupan masyarakat berkembang seperti dewasa ini telah dikenal kelompok yang masih bersifat sederhana, primitif dan kecil dalam bentuk sukusuku, kesatuan daerah, kesatuan turunan. Dengan adanya kelompok manusia yang disebut masyarakat, kemudian timbul adanya kepentingankepentingan secara bersama bagi masyarakat itu sendiri. Penyelenggara daripada masyarakat yang sederhana itu diurus dan diatur oleh orang-orang yang dituakan dalam masyarakat misalnya Kepala Suku, Kepala Marga.

Timbul masalah atas penyelenggaraan kepentingan bersama ini yaitu darimana biaya untuk menyelenggarakan kepentingan bersama ini. Adapun cara yang dilakukan antara lain yaitu memberikan tenaga dan waktu, memberikan harta miliknya dalam hal ini biasanya dalam bentuk natura: jagung, beras, ketela, dan bahkan sebagian harta. Perberian natura ini dianggap pajak dalam bentuk yang paling sederhana.

Sebelum masyarakat tersebut di atas melakukan "pembayaran pajak", pada zaman dahulu kala telah dilakukan pemungutan pajak yaitu oleh Zakheus (si pemungut pajak, kepala pemungut cukai) di kota Yerikho; walaupun dalam pelaksanaan pemungutan pajaknya Zakheus melakukan dengan cara memeras. Pemungutan pajak yang dilakukan Zakheus tersebut tidak sesuai dengan penyelenggaraan masyarakat sederhana tersebut dan apalagi untuk sekarang ini sudah tidak sesuai dengan peraturan perundang-undangan perpajakan, dimana kepentingan untuk rakyat dan penyelenggaraan negara. Si Zakheus memungut pajak dilakukannya untuk kepentingan sendiri. Namun, pada saat "insafnya" si Zakheus mengembalikan setengah dari miliknya (dari hasil pemungutan pajaknya) kepada orang miskin dan pemungutannya pajak yang dilakukannya dengan cara pemerasan dikembalikan si Zakheus kepada orang yang diperasnya sebanyak empat kali lipat. Itu berarti pemungutan pajak telah dilakukan dari zaman si Zakheus hingga sekarang ini.

Masyarakat yang tadinya sederhana (yang pembayaran pajaknya dilakukan dengan cara pemberian natura tadi) semakin lama semakin besar, sehingga memerlukan organisasi yang lebih besar, yaitu negara. Penanganan pemungutan pajak ini tidak lagi dilakukan oleh Kepala Suku, Kepala Marga, atau Kepala Kelompok, melainkan oleh negara yang bentuk penarikannya melalui peraturan perundang-undangan perpajakan. Dengan demikian, pemungutan pajak pun diartikan sebagai pemungutan sejumlah uang, yang 
mana hasil pemungutan pajak tersebut bukan untuk kepentingan perorangan (sebagaimana pada zaman si Zakheus) melainkan untuk kepentingan negara, masyarakat, dan pembayaran pembangunan bangsa.

Kemudian berkembang pungutan negara kepada rakyatnya pada zaman Romawi, yaitu dipungut pajak langsung dan pajak tidak langsung seperti pungutan atas penggunaan pelabuhan, dimana pemungutannya bukan oleh raja, melainkan raja mendelegasikan pemungutannya kepada Publican. Namun, setelah beberapa lama cara ini diubah oleh raja Roma kepada bendahara kaisar dan bendahara negara (Fiscus. Kata Fiscus berasal dari bahasa Latin yang artinya tempat penyimpanan uang atau bendahara negara), agar raja langsung mendapatkannya. Setelah itu berkembang zaman Julius Caesar dengan memungut pajak penjualan, merambah ke negara Spanyol dengan pajak penjualan, hingga ke Amerika Serikat pemungutan pajaknya berdasarkan diundangkannya The Stamp Act.

Sejarah singkat perpajakan di Indonesia sudah dimulai dari adanya kerajaan-kerajaan di Indonesia, yang pemungutannya dilakukan dalam bentuk pajak tanah, pajak barang dagangan, upeti yang diberikan kepada raja atau penguasa. Hasil pajak yang diterima oleh raja atau untuk penyelenggaraan pemerintah setempat, membiayai pertahanan-kekuatan raja, sehingga rakyat mendapat pelayanan dan jaminan ketertibankeamanan. Kemudian berkembang ke zaman kedatangan VOC yang mengenakan pajak: usaha, rumah, dan pajak kepala kepada para pedagang, pajak penjualan barang di pasar. Yang perlu diingat bahwa pada zaman penjajahan pajak itu dieksploitasi untuk si penjajah guna mengisi pundipundi kas pemerintahan si penjajah, sedangkan rakyat Indonesia tidak merasakan dampak dari pemungutan pajakitu sendiri

Sebenamya, rakyat membayar pajak dengan ikhlas merupakan pemberian sebagian harta yang diberikan oleh rakyat kepada negaranya dengan tanpa imbalan secara langsung, sehingga sudah sepantasnya pemungutan pajak hanus berdasarkan persetujuan dari rakyat yang diwakili di lembaga perwakilan rakyat agar tidak ada kesewenang-wenangan tersebut. Keterwakilan melalui wakil rakyat dilakukan dengan cara pembuatan undang-undang perpajakan yang berisikan: subjek pajak, objek pajak, tarif pajak, prosedur perpajakannya, dan dasar perhitungan penghasilan kena pajak.

Perkembangan pajak di Indonesia setelah era zaman Belanda dan juga Jepang (yang pengenaan pajaknya hampir sama dengan zaman Belanda misalnya pajak tanah), dapat dibagi kepada sejarah perpajakan: Pajak Bumi dan Bangunan, pajak penghasilan pajak perseroan. Hal ini ditandai dengan adanya pajak tuan tanah dengan suatu jumlah yang tetap, adanya pengelolaan tanah yang dikenakan kepada para petani, kemudian adanya aturan tentang sewa tanah. Pajak penghasilan ditandai dengan pengenaan pajak kepada untuk orang pribumi, orang asing Asia, dan orang Eropa. Pajak penghasilan ini tahun 1920-an disebut dengan pajak Pendapatan yang ditandai dengan Ordonansi Pajak Pendapatan 1920, setelah itu dibuatlah pajak kekayaan, dan berubah lagi kepada Ordonansi Pajak Pendapatan 1944, dan pemerintah mengubah maupun menambahnya hingga tahun 1970.

Adapun untuk pajak perseroan di Indonesia pengenaannya dimulai tahun 1925 yang dikenal dengan penyebutan Ordonansi Pajak Perseroan 1925, dimana subjeknya adalah perusahaan-perusahaan, sedangkan objeknya adalah laba bersih dari perusahaan-perusahaan tersebut. Ordonansi Pajak Perseroan 1925 dilakukan perubahan dan penambahannya menjadi suatu undang-undang di tahun 1970.

Berdasarkan ketetapan MPR Nomor II/MPR/1983 dilakukanlah tax reform, dimana dilakukan pembaruan dan penggantian atas peraturan perundang-undangan perpajakan selama kurun waktu lalu, misalnya untuk pajak bumi dan bangunan, pajak penghasilan, pajak rumah tangga, pajak kekayaan, pajak barang-barang tidak bergerak, pajak perseroan, pajak penghasilan, yang pelaksanaannya dimulai pada 1 Januari 1984 
ditandai dengan sistem perpajakan Indonesia berubah dari Official Assessment menjadi Self Assessment (namun perlu diingat pula bahwa Official Assessment-nya masih ada yang dipakai, yaitu dalam hal penerapan penghitungan untuk Pajak Bumi dan Bangunan). Kemudian seiring dengan perkembangan ekonomi dan perkembangan zaman, ada pajak pertambahan nilai yang sebelumnya merupakan pajak penjualan, bea materai, bea perolehan hak atas tanah dan bangunan, pajak-pajak daerah antara lain: pajak reklame, pajak hiburan, pajak penerangan jalan, pajak hotel dan restoran, dan sebagainya. Untuk pelaksanaan perpajakan dengan adanya tax reform, dibuatlah undang-undang perpajakan yang awalnya dimulai di tahun 1983, 1984, 1994, 2000, hingga ke periode $2007 \mathrm{~s} / \mathrm{d} 2009$.

Berbagai macam pungutan pajak dan pungutan selain pajak yang ada di Indonesia diatur melalui UU beserta peraturan pelaksana selain UU. Hal ini merupakan kewajiban kepada negara yang diformalkan sehingga setiap orang yang dikenakan pajak harus taat dan patuh membayar pajak sesuai UU. Pajak bersifat memaksa digunakan untuk kepentingan negara. Berdasarkan hukum pajak setiap wajib pajak membayar pajak jika sudah memenuhi syarat formil dan materiil. Oleh karena itu, secara hukum formil negara harus mengatur tata cara bagaimana orang pribadi/badan harus mendaftarkan diri menjadi wajib pajak, ketentuan membayar pajak, ketentuan menyetor pajak, pembetulan pajak, pemeniksaan petugas pajak, penetapan pajak sampai sanksi dan hapusnya utang pajak. Kemudian negara juga mengatur secara materiil obyek dan tarif pajak yang berlaku.

Menurut lembaga pemungutnya pajak dibagi menjadi dua yaitu pajak negara (pajak pusat) dan pajak daerah.

1. Pajak Negara (Pajak Pusat)

Pajak yang dipungut pemerintah pusat yang penyelenggaraannya dilaksanakan oleh Departemen Keuangan dan hasilnya akan digunakan untuk pembiayaan rumah tangga negara pada umumnya.

a. Pajak yang dipungut oleh Dirjen Pajak:
- Pajakpenghasilan

- PPN (penyerahan lokal)

- Pajak Bumi dan Bangunan

- Bea Materai

- BeaLelang

b. Pajak yang dipungut Bea Cukai (Dirjen Bea Cukai)

2. PajakDaerah

Pajak-pajak yang dipungut oleh daerah seperti Propinsi, Kabupaten maupun Kotamadya berdasarkan peraturan daerah masing-masing dan hasilnya digunakan untuk pembiayaan Rumah Tangga masing-masing.

a. Pajak-pajak tingkat Propinsi

- Pajak Kendaraan Bermotor

- Bea Balik Nama Kendaraan Bermotor

- Bea Balik Nama Tanah (Pulasi)

- Pajak izin penangkapan ikan diwilahnya

b. Pajak-pajak tingkat Kabupaten/ Kotamadya

- Pajak atas pertunjukan dan Keramaian Umum

- Pajak atas reklame

- Pajak Anjing

- Pajak atas kendaraan tidak bermotor

- Pajak Pembangunan

- Pajakradio

- Pajak Jalan

- Pajakbangsa asing

- Pajak potong hewan

c. Macam-macam Pajak yang lain:

- Bea Jalan/Jembatan

- Bea Pangkalan

- Bea Penambangan

- Uang sempadan/izin bangunan

- Uang atas penguburan

- Uang pengujian kendaraan bermotor

- Retribusi jembatan timbang

- Retribusi stasiun bis, taxi

- Retribusi tempat rekreasi

- Retribusi pasar

- Retribusi pesanggrahan 
- Retribusi pelelanganikan

Menurut UU Nomor:18 Tahun 1997 tentang Pajak Daerah dan Retribusi Daerah sebagaimana telah diubah dengan UndangUndang Nomor:34 Tahun 2000 tentang Perubahan atas Undang-Undang Nomor:18 Tahun 1997 tentang Pajak Daerah dan Retribusi Daerah dan terakhir Undang-Undang Nomor:28 Tahun 2009 perlu disesuaikan dengan kebijakan otonomi daerah, jenis-jenis pajak daerah dan retribusi yang berlaku sebelumnya mengalami perubahan. Isi pokok dari Undang-undang ini pada dasamya merinci kembali jenis-jenis pajak dan retribusi yang berlaku sebelumnya. Jenis-jenis Pajak Daerah Tingkat I ditetapkan sebanyal 3 (tiga) jenis pajak, sedangkan jenis-jenis Pajak Daerah Tingkat II sebanyak 6(enam) jenis pajak. Sedabgkan retribusi dikenakan terhadap jasa-jasa yang disediakan oleh Pemerintah Daerah. Jasa tertentu tersebut dikelompokkan menjadi tiga golongan, yaitu jasa Umum, jasa Usaha dan perizinan tertentu.

Berikut ini adalah jenis-jenis pajak daerah menurut UU No.18 Tahun 1997 tentang Pajak Daerah dan Retribusi Daerah sebagaimana telah diubah dengan Undang-Undang Nomor:34 Tahun 2000 tentang Perubahan atas Undang-Undang Nomor:18 Tahun 1997 tentang Pajak Daerah dan Retribusi Daerah dan terakhir Undang-Undang Nomor:28 Tahun 2009

1. Jenis-jenis Pajak Daerah

a. Daerah Tingkat I

1. Pajak Kendaraan Bermotor (PKB), menupakan pajak atas pemilikan dan atau penguasaan bermotor.

2. Bea Balik Nama Kendaraan Bermotor adalah pajak atas penyerahan hak milik kendaraan bermotor sebagai akibat perjanjian dua pihak atau perbuatan sepihak atau keadaan yang terjadi karena jual beli, tukar menukar, hibah, warisan atau pemasukan ke dalam badan usaha.
3. Pajak Bahan Bakar Kendaraan Bermotor adalah pajak atas bahan bakar yang disediakan atau dianggap digunakan untuk kendaraan bermotor.

b. Daerah Tingkat II

1. Pajak Hotel dan Restoran adalah pajak atas pelayanan hotel dan restoran.

2. Pajak Hiburan adalah atas penyelenggaraan Hiburan.

3. Pajak Reklame adalah pajak atas penyelenggaraan Reklame.

4. Pajak Penerangan Jalan adalah pajak atas penggunaan tenaga listrik, dengan ketentuan di daerah tersebut tersedia penerangan jalan, yang rekeningnya dibayar oleh pemerintah daerah.

5. Pajak pengambilan dan Pengolahan Bahan Galian Golongan $\mathrm{C}$ adalah pajak atas kegiatan eksploitasi bahan galian golongan $\mathrm{C}$ sesuai dengan peraturan yang berlaku.

6. Pajak Pemanfaatn Air Bawah Tanah dan Air Permukaan adalah pajak pengambilan air bawah tanah dan atau air permukaan untuk digunakan bagi orang pribadi atau badan kecuali untuk keperluan dasar numah tangga dan pertanian rakyat.

2. Retribusi Daerah

a. Jasa Umum, antara lain pelayanan kesehatan dan pelayanan persampahan.

b. Jasa Usaha, antara lain: penyewaan aset yang dimiliki atau yang dikuasai oleh Pemerintah Daerah, penyediaan tempat penginapan, usaha bengkel kendaraan, tempat pencucian mobil dan penjualan bibit. 
c. Perijinan Tertentu yang masih dapat dipungut retribusi antara lain. Izin Mendirikan Bangunan, Izin Peruntukan Penggunaan Tanah.

Sebagai landasan hukum dilakukannya pemungutan oleh pemerintah daerah UndangUndang Nomor 25 Tahun 1999 tentang Perimbangan Keuangan Antara Pemerintah Pusat dan Daerah, mengatakan bahwa pemerintah dan masyarakat di daerah dipersilahkan mengurus rumah tangganya sendiri secara bertanggung jawab. Pembangunan daerah sebagai bagian integral dari pembangunan nasional dilaksanakan melalui otonomi daerah dan pengaturan sumber daya nasional, yang memberi kesempatan bagi peningkatan demokrasi dan kinerja daerah yang berdaya guna dan berhasil guna dalam penyelenggaraan pemerintahan, pelayanan masyarakat dan pembangunan untuk meningkatkan kesejahteraan masyarakat menuju masyarakat madani yang bebas korupsi, kolusi dan nepotisme, untuk itu diperlukan keikutsertaan masyarakat, keterbukaan dan pertanngungjawaban kepada masyarakat. Pemerintah pusat melakukan fungsi supervisi, memantau, mengawasi dan mengevaluasi pelaksanaan kegiatan tersebut melallui fungsi otonomi daerah. Pemerintah daerah diberikan wewenang untuk mengatur dan mengurus rumah tangga daerahnya. Langkahlangkah yang perlu diambil dengan cara menggali segala kemungkinan sumber keuangannya sendiri sesuai dengan dan dalam batas-batas peraturan perundang-undangan yang berlaku. Pelaksanaan otonomi daerah maka sumber pembiayaan pemerintah daerah tergantung pada peranan pendapatan asli daerah. Pemerintah daerah harus dapat mengupayakan peningkatan penerimaan yang berasal dari daerah sendiri sehingga akan memperbesar tersedianya keuangan daerah yang dapat digunakan untuk berbagai kegiatan pembangunan. Semakin memperbesar keleluasaan daerah untuk mengarahkan penggunaan keuangan daerah sesuai dengan rencana, skala prioritas dan kebutuhan daerah yang bersangkutan.

Pembangunan daerah sebagai bagian integral dari pembanguan nasional dilaksanakan berdasarkan prinsip otonomi daerah dan pengaturan sumber daya nasional yang memberikan kesempatan bagi peningkatan demokrasi dan kinerja daerah untuk meningkatkan kesejahteraan masyarakat menuju masyarakat madani yang bebas korupsi, kolusi dan nepotisme. Penyelenggaraan Pemerintahan Daerah sebagai sub sistem pemerintahan negara dimaksudkan untuk meningkatkan daya guna dan hasil guna penyelenggaraan pemerintahan dan pelayanan masyarakat. Sebagai daerah otonom, Daerah mempunyai kewenangan dan tanggung jawab menyelenggarakan kepentingan masyarakat berdasarkan prinsip-prinsip keterbukaan, partisipasi masyarakat dan pertanggung jawaban kepada masyarakat.

Untuk mendukung Otonomi Daerah diperlukan kewenangan yang luas, nyata dan bertanngung jawab di Daerah secara proporsionalyang diwujudkan dengan pengaturan, pembagian dan pemanfaatan sumber daya nasional yang berkeadilan serta perimbangan keuangan Pemerintah Pusat dan Daerah. Sumber pembiayaan pemerintahan Daerah dalam rangka perimbangan keuangan Pemerintah Pusat dan Daerah dilaksanakan atas dasar desentralisasi, dekonsentrasi dan tugas pembantuan.

Dalam Undang-Undang Nomor:28 Tahun 2009 sebagai pengganti Undang-Undang Nomor:18 Tahun 1997 dan Undang-Undang Nomor:34 Tahun 2000 tentang Pajak Daerah dan Retribusi Daerah, Pemerintah Pusat memberikan kewenangan yang lebih besar kepada daerah dalam perpajakan dan retribusi sejalan dengan semakin besamya tanggung jawab Daerah dalam penyelenggaraan pemerintah dan pelayanan kepada masyarakat. Lebih meningkatkan pertangung jawaban dalam penyediaan layanan dan penyelenggaraan pemerintahan dan sekaligus memperkuat otonomi daerah serta lebih memberikan kepastian bagi dunia usaha mengenai jenis-jenis pungutan daerah dan sekaligus memperkuat dasar hukum pemungutan pajak daerah dan retribusi daerah.

Daerah diberikan kewenangan yang lebih besar untuk mengatur dirinya sendiri, dengan 
maksud dan tujuan antara lain agar lebih mendekatkan pelayanan pemerintah kepada masyarakat serta memudahkan masyarakat untuk mengawasi penggunaan dana yang besumber dari Anggaran Pendapatan dan Belanja Daerah (APBD) sejalan dengan kewenangan tersebut, pemerintah daerah diharapkan lebih mampu menggali dan mengelola sumber-sumber pendapatan untuk memenuhi kebutuhan pembiayaan pemerintahan dan pembangunan di daerahnya. Pelaksanaan pembangunan daerah tidak terlepas dari kebijakan dan aturan daerah serta implementasi pelaksanaannya di tengah-tengah masyarakat, oleh karena itu ada beberapa faktor yang mempengaruhi dalam proses pelaksanaan pemerintahan daerah. Faktor tersebut yang paling utama adalah dari sumber daya manusia yaitu aparatur dari pemerintah itu sendiri. Sumber daya manusia atau aparatur pemerintahan itu sendiri memiliki peran penting dalam melaksanakan kegiatan-kegiatan dalam roda pemerintahan itu sendiri. Aparatur yang berkualitas akan menghasilkan pencapaian target pendapatan asli daerah dengan mudah, dalam hal ini pada bagian retribusi daerah.

Retribusi daerah pada Pemerintah Kota Palembang terdiri dari tiga bagian yaitu retribusi jasa umum penyelenggaraan transportasi, retribusi jasa usaha, dan retribusi izin trayek. Ketiga retribusi ini dijalani oleh salah satunya Dinas Perhubungan Kota Palembang. Ketiga retribusi ini pendapatan terbesar berasal dari retribusi jasa umum penyelenggaraan transportasi. Retribusi jasa umum penyelenggaraan transportasi menurut Peraturan Daerah (PERDA) Kota Palembang Nomor 16 Tahun 2011 Bab IPasal 1 baris 35 adalah retribusi atas jasa yang disediakan atau diberikan pemerintah daerah untuk tujuan kepentingan dan kemanfaatan umum serta dapat dinikmati oleh orang pribadi atau badan.

Retribusi parkir tepi jalan umum dipungut retribusi atas pelayanan yang disediakan tempat parkir di tepi jalan umum. Subjek dari retribusi pelayanan parkir tepi jalan umum adalah orang pribadi atau badan yang menggunakan atau menikmati pelayanan parkir tepi jalan umum. Objek dari retribusi itu sendiri adalah penyediaan pelayanan parkir tepi jalan umum yang ditentukan oleh pemerintah kota sesuai dengan ketentuan Peraturan Daerah (PERDA) nomor 16 tahun 2011 Bab II pasal 3,4,5. Kegiatan perparkiran, dalam hal ini kegiatan pemungutan retribusi parkir yang bertujuan untuk mendongkrak pendapatan asli daerah kota dari sektor dan retribusi, memuat banyak permasalahan-permasalah di dalamnya baik tantangan serta hambatan baik dari sisi pelaksanaan kegiatan pemungutan retribusi perparkiran maupun pengelolaan Pendapatan retribusi itu sendiri, seperti permasalahan organisasi dan manajemen yang ada di dinas serta Unit Pelaksana Teknis (UPT) perparkiran di Pemerintah Kota Palembang, sumber daya manusia yang melaksanakan kebijakan, kemudian infrastruktur berupa kelengkapan dan kesiapan peralatan yang akan menopang proses kegiatan tersebut serta dari sisi kematangan kebijakan tentang perparkiran itu sendiri.

Pendapatan asli daerah sebagai salah satu sumber penerimaan daerah mempunyai peran penting dalam pembangunan. Dilihat dalam pelaksanaan otonomi daerah dimana peranan Pendapatan Asli Daerah (PAD) diharapkan dan diupayakan dapat menjadi penyangga utama dalam membiayai kegiatan pembangunan di daerah. Pemerintah daerah harus dapat mengupayakan peningkatan penerimaan yang berasal dari daerah sendiri. Pungutan pajak dan retribusi daerah masih belum dapat dimanfaatkan secara optimal oleh daerah sebagai sumber pembiayaan desentralisasi. Keadaan ini diperlihatkan bahwa banyak permasalahan yang terjadi di daerah berkaitan dengan penggalian dan peningkatan Pendapatan Asli Daerah (PAD), terutama hal ini disebabkan oleh: relatif rendahnya basis pajak dan retribusi daerah, perannya yang tergolong kecil dalam total penerimaan daerah, kemampuan administrasi pemungutan di daerah yang masih rendah dan kemampuan perencanaan dan pengawasan keuangan yang lemah. Kondisi 
yang ada di Kota Palembang dengan potensi sumber daya alam yang sangat minim memaksa Pemerintah Kota Palembang untuk lebih kreatif mengoptimalkan potensi yang lain. Potensi yang memerlukan perhatian khusus dari Pemerintah Kota Palembang adalah penyelenggaraan retribusi parkir.

Mendukung kegiatan tersebut Pemerintah Kota Palembang telah mengeluarkan perda yang khusus mengatur sektor perparkiran ini, yaitu Perda Nomor 16 Tahun 2011 tentang retribusi jasa umum penyelengaraan transportasi dalam perda tersebut nama, subyek dan obyek retribusi terdapat pada bab II sedangkan ketentuan retribusi parkir terdapat pada bab IV. Salah satu sumber pendapatan asli daerah Kota Palembang adalah retribusi parkir. Retribusi parkir di tepi jalan umum merupakan jenis retribusi jasa umum yaitu pelayanan parkir di tepi jalan umum yang ditentukan pemerintah daerah.

Permasalahan retribusi atau retribusi daerah lebih tepatnya diatur dalam Peraturan Pemerintah Nomor 66 Tahun 2001 tentang retribusi daerah dimana yang dimaksud dengan retribusi daerah atau retribusi adalah pungutan daerah sebagai pembayaran atas jasa atau pemberian ijin tertentu yang khusus disediakan dan atau diberikan oleh pemerintah daerah untuk kepentingan orang pribadi atau badan. Retribusi jasa umum adalah pelayanan yang disediakan atau diberikan pemerintah daerah untuk tujuan kepentingan dan kemanfaatan umum serta dapat dinikmati oleh orang pribadi atau badan. Jenis-jenis retribusi jasa umum penyelengaraan transportasi yang diatur dalam Peraturaan Daerah Kota Palembang Nomor 16 Tahun 2011 Pasal 2, meliputi:

a. Pelayanan parkirdi tepijalan umum

b. Pengujian kendaraan bermotor

Retribusi parkir di tepi jalan umum yang di kelola oleh Pemerintah Kota Palembang merupakan upaya untuk meningkatkan pendapatan asli daerah dan merupakan salah satu pendapatan terbesar dari sumber pendapatan lain sehingga Pemerintah Kota Palembang mengawasi pelaksanaan retribusi parkir ini.

\section{METODE PENELITIAN}

Pelaksanaan penelitian ini untuk pengumpulan data primer maupun data sekunder menggunakan metode mixed melalui wawancara, terutama digunakan untuk menggambarkan (deskriptif) dan menjelaskan (explanatory atau confirmatory) tentang akuntabilitas retribusi parkir di Dinas Perhubungan Kota Palembang Tahun 2013. Adapun yang menjadi alasan pemilihan metode kualitatif adalah keinginan untuk menganalisis serta mengenal masalah dan mendapat pembenaran terhadap keadaan dan praktek-praktek yang sedang berlangsung, melakukan verifikasi untuk kemudian didapat hasil guna pembuatan rencana pada masa yang akan datang. Melalui wawancara dan observasi diharapkan hasil penelitian dapat mengungkapkan bagaimana akuntabilitas retribusi parkir di Dinas Perhubungan Kota Palembang Tahun 2013.

\section{HASIL DANPEMBAHASAN \\ Pertanggung jawaban Retribusi Parkir di Dinas Perhubungan Kota Palembang}

Dalam menilai jalannya akuntabilitas retribusi parkir di Dinas Perhubungan Kota Palembang aspek utama tersebut terdiri dari mekanisme pemungutan retribusi parkir, aktor yang melakukan pungutan retribusi parkir dan nilai yang di peroleh dari pungutan retribusi parkir tersebut. menggunakan teori akuntabilitas yang merupakan Teori J.B Ghartey dalam Muhammad Iqbal, Pengelolaan Keuangan Daerah (2012:79) yang mana pada teori ini memiliki tiga dimensi tolak ukur akuntabilitas dalam pemungutan yang dilaksanakan pada suatu instansi tersebut dilihat dari:

\section{A. Mekanisme Pemungutan Retribusi Parkir}

Mekanisme adalah tahapan atau proses dari alur pelaksanaan suatu kegiatan yang telah terorganisir dan sesuai dengan kebutuhan pelaksanaan kegiatan. Mekanisme dapat diartikan sebagai landasan atau tata cara dalam melaksanakan suatu kegiatan agar kegiatan tersebut dapat berjalan sesuai dengan alur yang diinginkan. 
Terdapat tiga indikator dalam mekanisme pemugutan retribusi parkir yaitu skema pelaksanaan retribusi parkir, mekanisme pelaksanaan retribusi parkir dan kepatuhan pelaksanaan skema pemungutan retribusi parkir.

\section{Skema Pelaksanaan Retribusi Parkir}

Terdapat empat macam keterangan tentang skema pelaksanaan, yaitu:

a. Skema sebagai suatu peta kognitif yang terdiri atas sejumlah ide yang tersusun rapi.

b. Skema sebagai kerangka referensi untuk merekam berbagai peristiwa atau data.

c. Skema sebagai suatumodel.

d. Skema sebagai suatu kerangka referensi terdiri atas respon-respon yang diberikan kemudian menjadi standar bagi respon-respon selanjutnya.

Skema pelaksanaan retribusi parkir di Dinas Perhubungan Kota Palembang memiliki Standar Operasional Pekerjaan (SOP) dimulai dari juru parkir, kolektor parkir, bendahara dinas perhubungan dan kepala UPTD perparkiran dinas perhubungan.

\section{Mekanisme Pelaksanaan Retribusi Parkir}

Mekanisme pemungutan retribusi parkir menurut Unit Pelaksana Teknis Dinas (UPTD) perpakiran dimulai dari pemilik kendaraan, dari pemilik kendaraan ke junu parkir di masing-masing titik parkir, setelah itu juru parkir menyetorkan uang retribusi ke kolektor parkir, dari kolektor parkir uang retribusi parkir kemudian disetorkan ke bendahara penerima pembantu Unit Pelaksana Teknis Dinas (UPTD) perparkiran, pada tahapan terakhir bendahara penerima Unit Pelaksana Teknis Dinas (UPTD) perparkiran menyetor langsung ke rekening dinas pendapatan daerah melalui Bank SumSel Babel. Alur di atas terlihat jelas bahwa setoran retribusi pada akhimya akan disetorkan ke Bank Sumsel Babel, dimana rekening yang dituju adalah dinas pendapatan daerah.

\section{Kepatuhan Pelaksanaan Skema Pemungutan Retribusi Parkir}

Tingkat kepatuhan para pelaksanaan pemungutan retribusi parkir yang dilakukan oleh Dinas Perhubungan Kota Palembang telah diatur dalam Standar Operasional Pekerjaan (SOP) sehingga aktor yang terlibat dalam pemungutan retribusi mumpunyai tugas dan fungsinya masingmasing. Berdasarkan fakta di lapangan masih ada kolektor parkir atau pun juru parkir yang bertindak curang. Karakteristik agen pelaksana dalam penetapan kolektor parkir pada segi pengawasan kegiatan kolektor parkir tidak terlalu ketat, pengawasan yang dilakukan hanya pada jumlah biaya retribusi yang disetorkan oleh kolektor parkir ke Unit Pelaksana Teknis Dinas (UPTD) perparkiran.

Pengawasan yang diberikan kepada kolektor parkir tidak terlalu mendalam, maksudnya tidak terlalu mendalam yaitu pada saat kolektor parkir melakukan pungutan ke juru parkir tidak terlalu ketat. Dengan adanya pengawasan yang tidak terlalu ketat ditakutkan akan ada oknumoknum yang sengaja memanfaatkan dan mengambil keuntungan dari hal tersebut. Penulis melakukan observasi dilapangan dengan mengikuti kolektor parkir dalam melakukan pungutan retribusi tidak ada indikasi kecurangan yang dilakukan oleh kolektor parkir dan juru parkir. Jumlah biaya retribusi yang disetorkan pun sesuai dengan apa yang sudah ditargetkan pada juru parkir tersebut. Kolektor parkir dalam melakukan pungutan mereka membawa sebuah buku kecil yang berisikan lokasi-lokasi parkir yang akan disetorkan dan besamya jumlah setoran tersebut, sehingga disini dapat disimpulkan bahwa walaupun kurangnya pengawasan yang dilakukan kolektor parkir tetap melaksanakan tugasnya sesuai dengan apa yang telah diperintahkan dan sesuai dengan fungsi mereka.

\section{Aktor Yang Terlibat Dalam Pemungutan Retribusi Parkir}

\section{Aktor Yang Terlibat}

Pelaksanaan retribusi parkir terdapat aktor yang terlibat dalam pemungutan parkir yaitu Juru parkir, kolektor parkir, bendahara dishub dan 
kepala unit pelaksana teknis dinas (UPTD) perparkiran.

\section{Tugas Dalam Pelaksanaan}

Aktor Pelaksaan pemungutan retribusi parkir yang dilakukan oleh Dinas Perhubungan Kota Palembang memiliki tugas masing-masing. Juru parkir memungut retribusi parkir dari pemilik kendaraan yang parkir di setiap titik parkir. Kolektor parkir mengumpulkan uang retribusi parkir yang dikumpulkan dari junu parkir. Bendahara Dinas Perhubungan menerima dan menyetorkan uang retribusi parkir ke rekening dinas pendapatan daerah. Kepala Unit Pelaksana Teknis Dinas (UPTD) membawahi dan mengawasi pemungutan retribusi parkir.

\section{Nilai Yang Diperoleh Dari Pungutan Retribusi Parkir}

\section{Target dan Realisasi}

Meningkatkan penerimaan Pendapatan Asli Daerah (PAD), pemerintah daerah perlu melakukan analisis potensi-potensi yang ada di daerah dan mengembangkan potensi tersebut sebagai pemasukan daerah. Pengembangan potensi akan menciptakan pendapatan asli daerah bagi yang berguna untuk melaksanakan tujuan pembangunan. Pengelolaan pendapatan asli daerah yang efektif dan efisien perlu dilaksanakan dengan mempertimbangkan kondisi ekonomi daerah maupun perekonomian nasional. Kontribusi yang dicapai dari pendapatan asli daerah dapat terlihat dari seberapa besar pendapatan tersebut disalurkan untuk membangun daerah agar lebih berkembang dan mampu meningkatkan kesejahteraan masyarakat. Pungutan pajak dan retribusi daerah masih belum dapat dimanfaatkan secara optimal oleh daerah sebagai sumber pembiayaan desentralisasi. Kondisi yang ada di Kota Palembang dengan potensi sumber daya yang minim memaksa Pemerintah Kota Palembang untuk lebih kreatif mengoptimalkan potensi yang lain, salah satu potensi yang memerlukan perhatian khusus adalah penyelenggaraan retribusi parkir.

Pemungutan retribusi parkir di Kota Palembang adalah salah satu dari pelaksanaan otonomi yang luas, nyata dan bertanggung jawab sebagai mana yang dimaksud dalam Undang-
Undang Nomor 32 Tahun 2004 tentang Pemerintahan Daerah. Otonomi daerah diperlukan upaya pemerintah daerah dalam menggali dan mengembangkan potensi daerah dalam rangka untuk memperoleh dana sehubungan dengan penyelenggaraan tugas pemerintahan dan pembangunan daerah.

Dinas Perhubungan Kota Palembang menetapkan angka yang telah ditargetkan pemerintah daerah untuk menetapkan Pendapatan Asli Daerah (PAD) di sektor Parkir. Ditinjau dari tahun 2010 sampai tahun 2013 ini retribusi parkir belum mampu mencapai target yang telah ditetapkan oleh Pemerintah Daerah Kota Palembang.

\section{KESIMPULANDANSARAN}

\section{A. Kesimpulan}

Hasil dari penjelasan dan penjabaran pada bab sebelumnya berdasarkan hasil wawancara dan turun kelapangan akuntabilitas retribusi parkir di Dinas Perhubungan Kota Palembang masih belum berjalan dengan baik, baik dan segi pengawasan yang dilakukan pihak Unit Pelaksana Teknis Dinas (UPTD) perparkiran maupun pelaksanaan yang dilakukan oleh para pelaksana di lapangan karena dari berbagai temuan di lapangan dan dari hasil wawancara yang telah dilakukan dan analisis menurut Teoti J.B Ghartey dalam Muhammad Iqbal, Pengelolaan Keuangan Daerah (2012:79) didapati masalah-masalah dan kendala sehingga akuntabilitas ini masih banyak yang perlu diperbaiki dan dilakukan pengawasan yang lebih ketatlagi.

Masalah yang pertamamasih banyaknyamata rantai pungutan parkir (preman), Kedua adanya titik parkir liar. Ketiga berkurangnya lahan parkir yang dipungut oleh instansi lain seperti Dinas Pendapatan (DISPENDA), Sistem Administrasi Manunggal Satu Atap (SAMSAT) dan Perusahaan Daerah (PD) Pasar. Ketiga masalah tersebut yang mempenganuhi tidak tercapainya target yang telah di tetapkan oleh Dinas Perhubungan Kota Palembang.

Berdasarkan yang telah disimpulkan di atas, faktor-faktor utama berdasarkan teori yang digunakan, 
faktor-faktor yang mempengaruhi akuntabilitas retribusi parkir di Dinas Perhubungan Kota Palembang terletak pada faktor sumber daya para pelaksana kegiatan itu sendiri, kemudian banyaknya parkir liar dan banyaknya titik parkiryang dipungut olehinstansi lain.

\section{B. Saran}

Berdasarkan hasil analisis dan kesimpulan di atas saran yang dapat diberikan dengan harapan akuntabilitas retribusi parkir dapat berjalan dengan baik ada enam hal pokok penting yang perlu diperhatikan dalam memaksimalkan retribusi parkir yaitu pertama petugas yang melakukan pengawasan di lapangan dalam hal ini kolektor sebaiknya diperketat lagi dalam mengawasi juru parkir. Kedua titik parkir liar harus diadopsi sebagai pemasukan retribusi parkir sehingga tidak masuk ke kantong-kantong pribadi. Ketiga target parkir harus dinaikan. Keempat zona parkir dikelompokkan per wilayah sehingga dalam pengumpulan retribusi dari juru parkir terorganisir. Kelima Sumber Daya Manusia (SDM) harus ditambah. Keenam titik parkir yang dipungut instansi lain sebaiknya diawasi sehingga instansi lain tidak mudah memungut retribusi dari titik parkir yang telah ditetapkan oleh dinas perhubungan.

\section{DAFTAR PUSTAKA}

Achmad Tjahjono, Muhammad Fakhri Husein. 2000. Perpajakan

Cahayati, Ati. 2003. Dasar-dasar Organisasi dan Manajemen. Jakarta: Grasindo.

Dr.Winardi, SE. 1986. Kamus Ekonomi

Drs. B. Usman, K. Subroto, SH. 1983. Pajak-Pajak Indonesia

DrsMardiasmo, MBA, Akt. 1995. Perpajakan

Effendi, Sofyan. 2013. Eyd Terbaru Permendiknas no 46 tahun 2009. Yogyakarta: Rona Pancaran Ilmu.

Fidel, SE,. SH, MM,. MH,. BKP. 2010. Cara memahami masalah-masalah Perpajakan
H. Bohari, SH., MS. 2001. Pengantar Hukum Pajak

IKAPI. 2013. Ketentuan Umum dan Tata Cara Perpajakan (K.U.P)

Ikhsan, Arfan. 2009. Pengantar Praktis Akuntansi. Yogyakarta: Grahallmu.

Indonesia Legal Center Publishing for Law and justice reform. 2009

Iqbal, Muhammad. 2012. Pengelolaan Keuangan Daerah. Yogyakarta: Sekolah Tinggi Ilmu Manajemen YKPN.

Maman Ukas. 2006. Manajemen (Konsep, Prinsip, Aplikasi)

Muhammad Idrus. 2009. Metode Penelitian Ilmu Sosial

Peraturan Daerah Kota Palembang Nomor 9 Tahun 2008 tentang Pembentukan, Susunan Organisasi dan Tata Kerja Dinas Daerah Kota Palembang.

Peraturan Daerah Nomor 16 Tahun 2011 tentang Retribusi Jasa Umum.

Peraturan Daerah Nomor 2 Tahun 1995 tentang Pembentukan, Organisasi, dan Tata Kerja Dinas Lalu Lintas Angkutan Jalan (LAJ).

Peraturan Pemerintah No. 66 Tahun 2001 tentang Retribusi Daerah.

Peraturan Pemerintah Nomor 22 tahun 1990 tentang Penyerahan Sebagian Urusan Pemerintahan Bidang Lalu Lintas dan Angkutan Jalan Kepala Daerah Tingkat I dan Daerah Tingkat II.

Pusat Bahasa Departemen Pendidikan Nasional 2005 Kamus Besar Bahasa Indonesia (Edisi ke 3). 2005

R. Soedargo, SH. 1960. Padjak Daerah dan Retribusi Daerah.

Sugiyono. 2013. Metode Penelitian Kuantitatif, Kualitatif dan $R \& D$. Bandung: Alfabeta 
Undang-Undang Nomor 14 Tahun 1992 tentang Lalu Lintas dan Angkutan Jalan.

Undang-Undang Nomor 17 Tahun 2003 tentang Keuangan Negara.

Undang-Undang Nomor 25 Tahun 1999 tentang Otonomi Daerah.

Undang-Undang Nomor 25 Tahun 1999 tentang

Perimbangan Keuangan Pusat dan Daerah.

Undang-Undang Nomor 28 Tahun 2009 tentang Pajak Daerah dan Retribusi Daerah.

Undang-Undang Nomor 32 Tahun 2004 tentang Pemerintahan Daerah.
Undang-Undang Nomor 33 Tahun 2004 tentang Perimbangan Keuangan Antara Pemerintah Pusat dan Daerah.

Waluyo, 2009. Perpajakan Indonesia (Buku 2 Edisi 8) Waluyo, Wirawan B. Ilyas (Buku 1). 2003. Perpajakan Indonesia. 